\title{
A Contrastive Analysis of Domestic Wall Materials Based on Green Energy Conservation and Emission Reduction
}

\author{
Jingrong $\mathrm{WU}^{1, \mathrm{a}}$ and Zhengjie $\mathrm{ZHAN}^{2, \mathrm{~b}}$ \\ ${ }^{1}$ Hubei University of Technology Engineering and Technology College, China \\ ${ }^{2}$ Hubei University of Technology Engineering and Technology College, China \\ a864877562@qq.com ${ }^{1}, 646226429 @ q q . c o m$
}

\begin{abstract}
. energy conservation and emission reduction is an extremely important task to be fulfilled by our country ${ }^{[1]}$. As a big energy consumer of the building industry, the energy consumption of the building industry covers $40 \%-50 \%$ of the social total energy consumption. Since China is in urgent need of energy, the application of energy conservation and emission reduction technology is of great significance for relieving the energy tension, so it is a pressing task for the building industry to study new wall materials ${ }^{[2]}$.This paper carries out a contrastive analysis of three wall materials which are most widely used in our county.
\end{abstract}

\section{Introduction}

Presently, increasingly tense energy source, serious environmental pollution and ever-increasing building energy consumption are caused by the accelerating urbanization of our country and the growing investment in the building industry, as a result, building energy conservation has been increasingly concerned, and energy conservation and emission reduction becomes an extremely important task of the Chinese society. However, building cannot be separated from materials.The 12th Five-Year Plan for Energy Conservation and Emission Reduction was issued by the State Council in 2012, which requires to establish the forcing mechanism for accelerating the change of the economic development mode, substantially improve the efficiency of energy utilization, greatly reduce the pollutant emission, realize a decrease of $16 \%$ of unit energy consumption of gross domestic product (GDP) in 2015 compared to 2010, According to statistics of the Department of Building and Housing, wall materials cover about $70 \%$ of building materials and the energy consumption of walls covers about $50 \%$ of that of buildings, therefore, the innovation of wall materials will greatly improve the functionality of buildings and sharply lower the construction cost.

\footnotetext{
* Corresponding author: 864877562@qq.com
} 


\section{Existing Main New Wall Materials}

From the point of purpose, new wall materials can be divided into building blocks, bricks and boards. New wall materials are called "new type wall materials and products" in English. Energy-saving materials intended for walls mainly cover concrete blocks consisting concrete, cement, sand and other silicic acid materials, fired hollow bricks, fired solid bricks and hollow bricks obtained from pressing or sintering, steam curing or steam pressing coal gangues of power plant, coal ash, industrial tailings, industrial slag or construction wastes, foam concrete and aerated concrete featuring ${ }^{[5]}$ good thermal insulation property and energy conservation of daily use, gypsum plaster and related building materials with low energy consumption of daily use, lime-sand bricks and hollow interior partition boards produced from industrial wastes and GRC light wallboard.This paper mainly analyzes Dinas brick, autoclaved aerated concrete block and GRC light wallboard.

\section{Comparison of Three Wall Materials}

\subsection{Dinas Brick}

Dinas brick is a new wall material made of lime and river sand through mixed compression molding and steam high temperature and high pressure processing. It features high intensity, shape tidiness, durable service and unnecessary soil sample from field destroying and has been widely used for industrial and civil constructions.

PERFORMANCE AND SPECIFICATION ARE SHOWN IN TABLE 1

TABLE 1

\begin{tabular}{|c|c|c|c|c|c|c|}
\hline $\begin{array}{c}\text { Ite } \\
\mathrm{m}\end{array}$ & $\begin{array}{c}\text { Specification (mm) } \\
\mathrm{L} \times \mathrm{W} \times \mathrm{H}\end{array}$ & $\begin{array}{c}\text { Hollow rate } \\
\%\end{array}$ & $\begin{array}{l}\text { Volume } \\
\text { weight } \\
\mathrm{kg} / \mathrm{m}^{3}\end{array}$ & $\begin{array}{l}\text { Compre } \\
\text { ssive } \\
\text { strength } \\
\mathrm{Mpa}\end{array}$ & $\begin{array}{c}\text { Shrinking } \\
\text { percentag } \\
\mathrm{e} \\
\mathrm{mm} / \mathrm{m}\end{array}$ & \begin{tabular}{|c|} 
Water \\
absorptio \\
$\mathrm{n}$ \\
\\
$\%$ \\
\end{tabular} \\
\hline DF & $240 \times 115 \times 53$ & 0 & $\leq 1850$ & \multirow{3}{*}{$\geq 10$} & \multirow{3}{*}{$0.3 \sim 0.4$} & \multirow{3}{*}{$<15$} \\
\hline $\begin{array}{c}2 \mathrm{D} \\
\mathrm{F}\end{array}$ & $240 \times 115 \times 115$ & 12 & $\leq 1600$ & & & \\
\hline $\begin{array}{c}3 \mathrm{D} \\
\mathrm{F}\end{array}$ & $240 \times 175 \times 115$ & 26 & $\leq 1400$ & & & \\
\hline
\end{tabular}

\subsection{Scope of Application}

It has been widely used for industrial and civil constructions, bearing walls and non-bearing walls.

Advantages and Disadvantages:

Advantages: 1) Wide scope of application, available for bearing walls and non-bearing walls; 2) Tidy shape and correct size, especially solid Dinas brick and red brick (solid clay brick) have the same size, it can be easily accepted for the convenience of use; 3) High intensity and good durability, especially it can replace red brick and be used for basement 
partition and outdoor enclosure wall after red brick is forbidden to be used; 4) Earlier application, mature technology.

Disadvantages: 1) Large volume weight, especially solid Dinas brick has the same volume weigh with red brick, energy conservation and economic effects are not obvious enough; 2) It can easily cause air shrinkage and fissure of the plaster layer due to large water absorption, attention should be paid to construction and effective measures should be taken.

\subsection{Common Concrete Hollow Block}

\section{PRODUCT SPECIFICATION AND PHYSICAL PROPERTIES ARE SHOWN IN TABLE 2}

TABLE 2

\begin{tabular}{|c|c|c|c|c|c|c|c|}
\hline Variety & Model & $\begin{array}{c}\mathrm{L} \times \mathrm{W} \times \mathrm{H} \\
\text { Specification } \\
(\mathrm{mm})\end{array}$ & $\begin{array}{l}\text { Volume } \\
\text { weight } \\
\mathrm{KG} / \mathrm{m}^{3}\end{array}$ & $\begin{array}{l}\text { Hollow } \\
\text { rate (\%) }\end{array}$ & $\begin{array}{c}\text { Compressi } \\
\text { ve strength } \\
\text { (Mpa) }\end{array}$ & $\begin{array}{c}\text { Water } \\
\text { absorpti } \\
\text { on } \\
(\%)\end{array}$ & $\begin{array}{c}\text { Heat } \\
\text { conductivit } \\
\mathrm{y} \\
\text { coefficient } \\
(\mathrm{W} / \mathrm{m} \cdot \mathrm{K})\end{array}$ \\
\hline \multirow{3}{*}{ Outer wall } & A & $390 \times 190 \times 190$ & \multirow{3}{*}{$1100 \sim$} & 47.0 & \multirow{7}{*}{$3.5-5.5$} & \multirow{7}{*}{$<13$} & \multirow{7}{*}{$<0.5$} \\
\hline & B & $190 \times 190 \times 190$ & & 41.4 & & & \\
\hline & $\mathrm{C}$ & $390 \times 140 \times 190$ & & 33.5 & & & \\
\hline \multirow{4}{*}{$\begin{array}{c}\text { Interior } \\
\text { wall }\end{array}$} & D & $390 \times 115 \times 190$ & \multirow{4}{*}{$\begin{array}{l}1200 \sim \\
1300\end{array}$} & 36.4 & & & \\
\hline & $\mathrm{E}$ & $190 \times 115 \times 190$ & & 28.0 & & & \\
\hline & $\mathrm{F}$ & $390 \times 90 \times 190$ & & 30.9 & & & \\
\hline & G & $190 \times 90 \times 190$ & & 15.5 & & & \\
\hline $\begin{array}{l}\text { Solid } \\
\text { brick }\end{array}$ & $\mathrm{H}$ & $240 \times 120 \times 90$ & 1500 & 0 & $5.5-7$ & $<15$ & --- \\
\hline
\end{tabular}

Advantages and Disadvantages:

Advantages: 1) Light weight, concrete hollow block is about $1 / 3$ lighter than red brick and can reduce the dead weight of buildings. 2) High compressive strength, it is applicable to filler walls of various industrial and civil buildings and can be used as bearing walls, especially solid concrete block. concrete block is widely used in some places such as Shanghai City, and often replace red brick and is used as bearing walls in brick-concrete structures. Reinforced concrete block has been successfully used as bearing structure of 18-storey residential buildings in Shanghai City. 3) It features sound insulation, thermal insulation, damp resistance, fire resistance, corrosion resistance and other high properties. 
Disadvantages: featuring hollowness, it has poor performance of nailing and load bearing. Embedded pipes are inferior to those containing solid masonry.

\subsection{GRC Light Wallboard}

GRC is the abbreviation of Glass Fiber Reinforced Cement. GRC light wallboard is a new composite cement product with low-alkaline special cement as the binding material which is intensified with alkali containing glass fiber and molded through specific manufacturing technique. Featuring light weight, water resistance, sound insulation, heat preservation and insulation, strong machinability and convenient construction, it is applicable to non-bearing family splitting, room splitting, kitchen and toilet partition of buildings as well as prefabricated houses, temporary buildings and storey adding of old buildings etc.

\subsection{Specification and dimension}

It contains silicious GRC light wallboard, ceramsite GRC light wallboard, little foam GRC light wallboard etc. It includes standard board, door frame board, window frame board, lintel board and other irregular slabs.

Physical And Mechanical Properties Are Shown In Table 3

TABLE 3

\begin{tabular}{|c|c|c|c|c|c|}
\hline No. & Item & Unit & 60 series & 90 series & 120 series \\
\hline 1 & Surface density & $\mathrm{kg} / \mathrm{m}^{2}$ & $\leq 50$ & $\leq 60$ & $\leq 70$ \\
\hline 2 & $\begin{array}{c}\text { Drying shrinkage } \\
\text { value }\end{array}$ & $\mathrm{Mm} / \mathrm{m}$ & $\leq 0.7$ & $\leq 0.7$ & $\leq 0.7$ \\
\hline 3 & Air sound insulation & $\mathrm{dB}$ & $\geq 30$ & $\geq 40$ & $\geq 45$ \\
\hline 4 & Fire endurance & $\mathrm{H}$ & $\geq 1.5$ & $\geq 2.0$ & $\geq 2.5$ \\
\hline 5 & Combustibility & & Non-combust & Non-combust & Non-combust \\
& & & ible & ible & ible \\
\hline 6 & Fracture resistance & component & component & component \\
\hline 7 & Impact strength & Times & $\geq 5$ & $\geq 2.5$ & $\geq 2.0$ \\
\hline 8 & Hanging force & $\mathrm{N}$ & $\geq 800$ & $\geq 800$ & $\geq 800$ \\
\hline
\end{tabular}

Advantages and Disadvantages:

Advantages: 1) Light weight, high intensity, deformation resistance; 2) Water resistance, damp resistance, non-combustible, good heat preservation property; 3) Good machinability, nailing property, sawing property and drilling property; 4) Strong decorative property, good 
cohesiveness with putty, paint, adhesives, cement mortar and decorative tiles; 5) Easy and convenient to install; 6) Good surface evenness, two-sided plastering and wet construction are not required; 7) A usable area of $3-5 \%$ is added;

Disadvantages: it is mainly applicable to filler inner walls but inapplicable to outer walls, fissure can be easily caused at the joint due to transverse shrinkage of slab and requires special treatment at a high cost.

\section{Prospects of Green New Wall Materials}

Repeated experiments showed, new wall materials have the advantages of light weight (excluding Dinas bricks), high sound insulation and thermal insulation etc. There are also shortages: on one hand, new wall materials are more expensive (compared with clay brick) and the total construction cost will thus be increased; on the other hand, new wall materials can easily cause fissures due to air shrinkage. Presently, the government plays a guiding role in attaching importance to popularization and application of energy-saving buildings and conducting vigorous propaganda due to energy tension, atmospheric haze and environmental pollution. Moreover, the expectation for the comfort of buildings and a good living environment drives everyone to popularize energy-saving buildings and to concern about buildings and circumstances closely related to our survival ${ }^{[5]}$. External wall materials are endowed with a new significance specifically for green environmental protection in the future life ${ }^{[6]}$.

\section{References}

1. The $12^{\text {th }}$ Five-Year Plan for Energy Conservation and Emission Reduction issued by the State Council

2. Xianghai Li, Promotion and Application of New Wall Materials, [journal article] A Research on City Construction Theory, 2015

3. Taojing Chen, A discussion about development and application of energy-saving building materials, Chinese Folk House: Academic, 2011, (1)

4. National standard of the People's Republic of China GB13544-2003, GB11945-1999, GB11968-2006, JGJ/T157-2008

5. Lina $\mathrm{Hu}, \mathrm{A}$ Brief Discussion about Development and Suggestions of New Wall Materials, [journal article] Guide of Sci-tech Magazine, 2010

6. Fuguang Chen, Strategic Thinking of Wall Material Innovation, Fly Ash Comprehensive Utilization 2010, (2) 2010 